\title{
Microsatellite abnormalities in plasma of patients with breast carcinoma: concordance with the primary tumour
}

\author{
Frederick Mayall, Stefan Fairweather, Richard Wilkins, Bridget Chang, Rebecca Nicholls
}

\begin{abstract}
Aims-To detect microsatellite abnormalities in the primary tumours and plasma of patients with breast carcinoma. Methods-Plasma was obtained from 17 breast carcinoma patients before surgery. Corresponding tumour and benign lymph node (control) samples for each of the carcinoma patients were obtained from paraffin blocks. DNA was extracted from the plasma samples and the paraffin embedded tissue using previously described methods.

Results-The 17 primary tumours showed two examples of loss of heterozygosity and three examples of microsatellite instability; the 17 plasma samples showed three and one, respectively. Many of the longer microsatellites (over 200 base pairs) were difficult to amplify from plasma. The investigations suggested that this was because of the highly fragmented nature of plasma DNA. Only one example of loss of heterozygosity and one example of microsatellite instability showed a concordant pattern in both primary tumour and plasma. These were both in the same patient.
\end{abstract}

Conclusions-DNA mutations concordant with those in the primary carcinomas can occasionally be detected in the plasma of patients with breast carcinoma. However, the frequency would have to be markedly improved before this could be of any diagnostic value.

(f Clin Pathol 1999;52:363-366)

Keywords: tumour markers; breast carcinoma; polymerase chain reaction; microsatellite

Department of Pathology, Waikato Hospital, Private Bag 3200, Hamilton, New

Zealand

F G Mayall

B Chang

R Nicholls

Department of

Biology, Waikato

University, Hamilton,

New Zealand

$S$ Fairweather

$\mathrm{R}$ Wilkins

Correspondence to: Dr Mayall.

email: mayallf@hwl.co.nz

Accepted for publication 28 January 1999

The small quantities of "free" DNA in plasma are often increased in cancer patients. ${ }^{1-4}$ It was thought that this increased DNA could be derived from cancer cells. High levels were associated with poor prognosis, and the levels decreased with treatment. ${ }^{56}$ In 1995 N-ras mutations were reported in the plasma DNA of leukaemic and myelodysplastic patients. ${ }^{6}$ In 1996 two reports showed concordance of the pattern of microsatellite alterations between the DNA of carcinomas of the head, neck, and lung and the DNA in the plasma. ${ }^{78}$ Concordance of K-ras mutations between colorectal carcinomas and plasma DNA was described in 1997. ${ }^{9}$ In 1998 our research group described concordant $\mathrm{p} 53$ gene mutations in plasma and large bowel carcinoma. ${ }^{10}$
The aim of our present study was to analyse the plasma of patients with breast carcinoma to see if there was evidence of mutant DNA from the tumour in the plasma. We did this by examining a set of microsatellite loci for evidence of loss of heterozygosity and evidence microsatellite instability.

\section{Methods}

COLLECTION OF SAMPLES

Plasma samples (approximately $1.5 \mathrm{ml}$ ) were collected from 17 patients with breast carcinoma. These were stored at $-70^{\circ} \mathrm{C}$. Corresponding tumour and benign lymph node (control) samples for each of the carcinoma patients were obtained from blocks of $10 \%$ formol saline fixed, paraffin embedded tissue. The paraffin embedded tissue was derived from surgery that was performed one or two days after the plasma was taken. There were no specific selection criteria for the patients in the study other than they were female, had a definite preoperative diagnosis of breast carcinoma, and were prepared to volunteer for the study.

PLASMA DNA EXTRACTION

We attempted two methods of DNA extraction from plasma. In the first method $150 \mu$ of a $5 \%$ Chelex 100 solution (Sigma-Aldrich) was added to $50 \mu \mathrm{l}$ of plasma, and incubated at $56^{\circ} \mathrm{C}$ for 30 minutes. The solution was then vortexed at high speed for 10 seconds and incubated in a boiling water bath for eight minutes. Again the solution was vortexed at high speed for 10 seconds, centrifuged for 10 minutes at $15000 \mathrm{~g}$, and stored at $4^{\circ} \mathrm{C}$. The supernatant was removed as required for polymerase chain reaction (PCR) reactions.

In the second method, $630 \mu \mathrm{l}$ of plasma was placed into $1.5 \mathrm{ml}$ Eppendorf tubes and triton $\mathrm{X}-100$ (BDH Chemicals) was added to a final concentration of $1 \%$. The Eppendorf tubes were incubated at $95^{\circ} \mathrm{C}$ for 20 minutes and centrifuged for 20 minutes at $17800 \mathrm{~g}$. The supernatant was recovered and the protein pel$\mu 1)$ provided a template for subsequent PCR reactions. We used the Chelex 100 method for most of the samples, for reasons outlined in Discussion.

EXTRACTION OF DNA FROM PARAFFIN BLOCKS Tissue was cut from the desired region of the paraffin block with a scalpel blade. This was dewaxed by washing twice in xylene and then twice in ethanol. DNA was extracted from the let discarded. Aliquots of this supernatant (2-5 
Table 1 Primer sequences and annealing temperatures used in the screening of breast cancer DNA

\begin{tabular}{|c|c|c|}
\hline Primer name & Primer sequence: forward $(F)$, reverse $(R)$ & $\begin{array}{l}\text { Annealing } \\
\text { temperature }\end{array}$ \\
\hline $\operatorname{AR}(X)$ & $\begin{array}{l}\text { 5'-TCCGCGAAGTGATCCAGAAC-3' (F) } \\
\text { 5'-CTTGGGGAGAACCATTCTCA-3' (R) }\end{array}$ & $56^{\circ} \mathrm{C}$ \\
\hline АСТВР2 & $\begin{array}{l}\text { 5'-AATCTGGGGACAAGAGTGA-3' (F) } \\
\text { 5'-ACTTCTCCCCTACCGCTATA-3' (R) }\end{array}$ & $60^{\circ} \mathrm{C}$ \\
\hline UT762 & $\begin{array}{l}\text { 5'-GTCAGTATTACCCTGTACCA-3' (F) } \\
\text { 5'-GTTGAGGATTTTTGCATCAGT-3' (R) }\end{array}$ & $57^{\circ} \mathrm{C}$ \\
\hline D14 & $\begin{array}{l}\text { 5'-AACACCCCTAATTCACCACT-3' (F) } \\
\text { 5'-ATGATTCCACAAGATGGCAG-3' (R) }\end{array}$ & $54^{\circ} \mathrm{C}$ \\
\hline DRLPA & $\begin{array}{l}\text { 5'-CACAGTCTCAACACATC-3' (F) } \\
\text { 5'-CCTCCAGTGGGTGGGGAAATGCTC-3' (R) }\end{array}$ & $53^{\circ} \mathrm{C}$ \\
\hline $\mathrm{FgA}$ & $\begin{array}{l}\text { 5'-CCATAGGTTTTGAACTCACAG-3' (F) } \\
\text { 5'-CTTCTCAGATCCTCTGACAC-3' (R) }\end{array}$ & $55^{\circ} \mathrm{C}$ \\
\hline $15 q 11$ & $\begin{array}{l}\text { 5'-TTGACCTGAATGCACTGTGA-3' (F) } \\
\text { 5'-TTCCATACCTGGGAACGAGT-3' (R) }\end{array}$ & $55^{\circ}$ \\
\hline GGAA4D07 & $\begin{array}{l}\text { 5'-GAGAGGGCAAGACTTGGAAG-3' (F) } \\
\text { 5'-ATGGAAGAGCGTTCTAAAACA-3' (R) }\end{array}$ & $57^{\circ} \mathrm{C}$ \\
\hline GGA2E02 & $\begin{array}{l}\text { 5'-AGGAAAGAGAAAGAAAGGAAGG-3' (F) } \\
\text { 5'-TATATGATGAAAGTATATTGGGGG-3' (R) }\end{array}$ & $57^{\circ} \mathrm{C}$ \\
\hline D18S34 & $\begin{array}{l}\text { 5'-CAGAAAATTCTCTCTGGCTA-3' (F) } \\
\text { 5'-CTCATGTTCCTGGCAAGAAT-3' (R) }\end{array}$ & $57^{\circ}$ \\
\hline D17S513 & $\begin{array}{l}\text { 5'-CATTCACTTGTGGGCTGCTGTC-3' (F) } \\
\text { 5'-TGTAAGAAAGGCTCCCACAAGCA-3' (R) }\end{array}$ & $57^{\circ} \mathrm{C}$ \\
\hline
\end{tabular}

dewaxed tissues according to Gemmell et $a l^{11}$ with some minor alterations. Briefly, tissue was resuspended in $200 \mu \mathrm{l}$ of $0.8 \% \mathrm{NaCl}$ and $250 \mu \mathrm{l}$ of lysis solution with $100 \mu \mathrm{g}$ of proteinase $\mathrm{K}$ and incubated overnight at $56^{\circ} \mathrm{C}$. Next, $120 \mu \mathrm{l}$ of $6 \mathrm{M} \mathrm{NaCl}$ and an equal volume of chloroform were added and the samples were mixed on a rotating wheel for 20 minutes and then centrifuged $(17800 \mathrm{~g})$ for 10 minutes. The supernatant was retrieved and the DNA precipitated by the addition of a half volume of $7.5 \mathrm{M}$ ammonium acetate and 2.5 volumes of $100 \%$ ethanol. Finally, the samples were centrifuged for 20 minutes, the DNA pellet washed in $70 \%$ ethanol, and resuspended in 50 $\mu \mathrm{l}$ of TE buffer (Tris HCL $10 \mathrm{mM}$ plus EDTA $1 \mathrm{mM})$.

POLYMERASE CHAIN REACTION

PCR was performed to amplify microsatellites that had shown high incidences of abnormali-

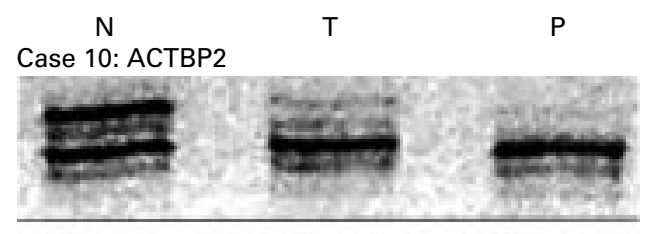

Case 10: FgA

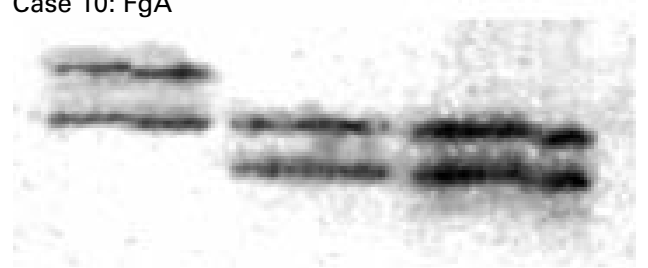

Figure 1 Denaturing polyacrylamide gel analysis for case 10. Lane $N$ is the product from the lymph node DNA, T is from the primary tumour, and $P$ is from the plasma. There is loss of heterozygosity for ACTBP2 and a band shift for $\mathrm{FgA}$, indicating microsatellite instability.

ties in previous studies, many of them on breast carcinomas (table 1). ${ }^{12-17}$ The reaction mix consisted of $2 \mu \mathrm{l}$ of DNA solution, $0.8 \mu \mathrm{M}$ of the reverse primer, $0.13 \mu \mathrm{M}$ of end labelled ${ }^{33} \mathrm{P}$ forward primer, $200 \mu \mathrm{M}$ each dNTP, $0.625 \mathrm{U}$ of Taq polymerase (Boheringer Mannheim), and $25 \mu \mathrm{l}$ of amplification buffer. A DNA engine (MJ Research) was used, with the following thermal cycling conditions: first round at $94^{\circ} \mathrm{C}$ for five minutes, followed by 35 cycles of $94^{\circ} \mathrm{C}$ for 30 seconds, $53-60^{\circ} \mathrm{C}$ (depending on the primer set used) for $30 \mathrm{sec}-$ onds, and $72^{\circ} \mathrm{C}$ for 30 seconds. Finally, the tubes were incubated at $72^{\circ} \mathrm{C}$ for five minutes then stored at $4^{\circ} \mathrm{C}$ for polyacrylamide gel analysis.

DENATURING POLYACRYLAMIDE GEL ANALYSIS Samples were run on a $6 \%$ denaturing polyacrylamide gel as described by Mao et al. ${ }^{18}$ Briefly, the PCR products were mixed with an equal volume of $95 \%$ gel loading buffer and denatured at $95^{\circ} \mathrm{C}$ for five minutes. A $5 \mu$ laliquot of each sample was loaded onto a $0.2 \mathrm{~mm}$ thick, preheated, denaturing $6 \%$ polyacrylamide gel and electrophoresed at $60 \mathrm{~W}(1500 \mathrm{~V})$ for 90 minutes. Following electrophoresis the gel was transferred to Whatman No 4 blotting

Table 2 Results of PCR of 11 microsatellite loci in samples of normal DNA, tumour, and plasma from 17 breast carcinoma patients

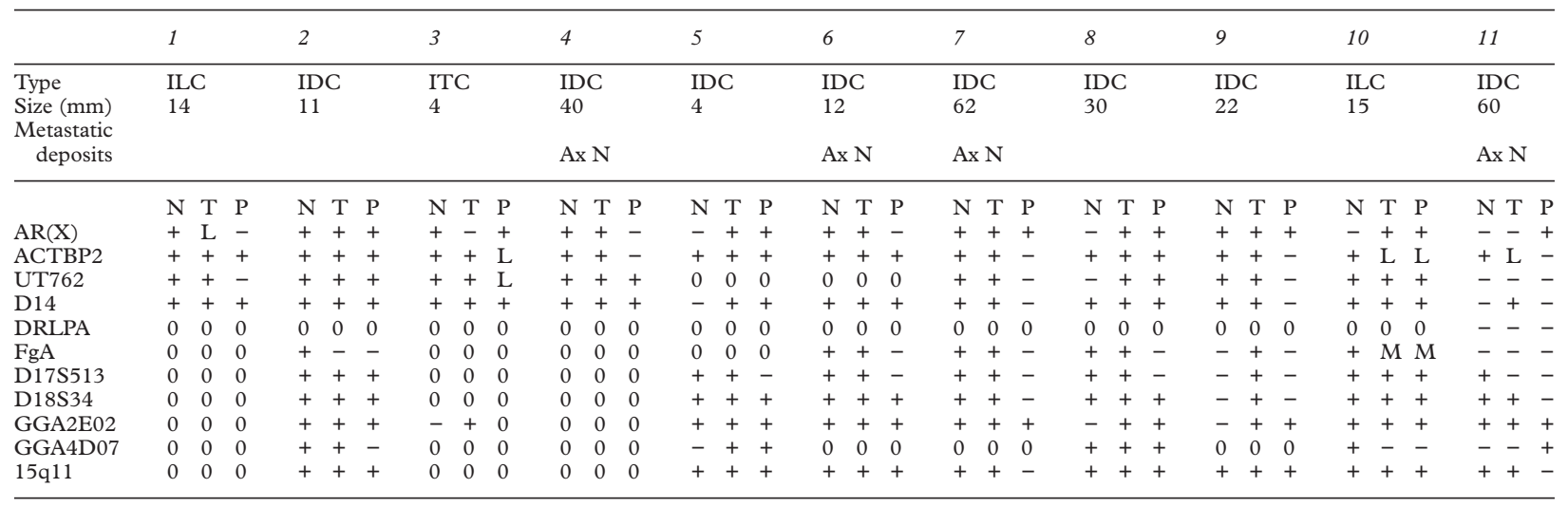

Ax N, axillary lymph node metastases; IDC, invasive ductal carcinoma; ILC, invasive lobular carcinoma; IMC, invasive mucinous carcinoma; ITC, invasive tubular carcinoma; L, loss of heterozygosity; $\mathrm{M}$, microsatellite instability; $\mathrm{N}$, benign lymph node sample; $\mathrm{P}$, plasma sample; $\mathrm{T}$, tumour sample; +, successful amplification;

- , unsuccessful amplification; 0 , amplification not attempted. 
$\mathrm{N}$

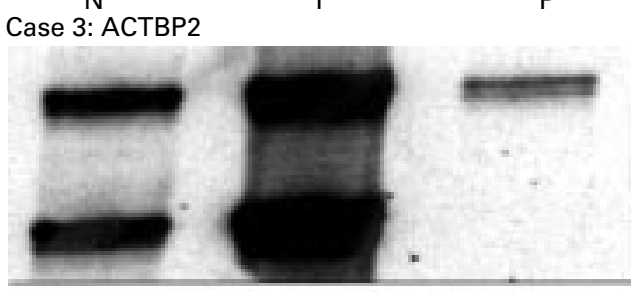

Case 3: UT762

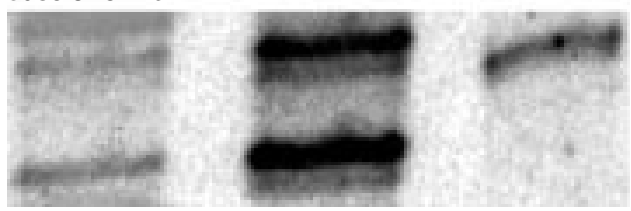

Figure 2 Denaturing polyacrylamide gel analysis for case 3. There is loss of heterozygosity in the plasma only for ACTBP2 for UT762.

paper and dried at $80^{\circ} \mathrm{C}$ for one hour on a gel drier. Dried gels were then exposed to Kodak scientific imaging film (type [X-OMAT] AR) for up to four days. The film was developed using Kodak developer and fix/stop solutions, then analysed for microsatellite instability and/or loss of heterozygosity.

\section{Results}

The results are presented in table 2 . Briefly of the 495 analyses attempted, 227 failed either because the PCR repeatedly failed to give a product (147) or because there was insufficient sample to attempt an analysis (80). Often repeated attempts at PCR for one microsatellite resulted in there being insufficient plasma sample to complete all of the other microsatellite PCR analyses. The larger microsatellites such as FgA had a particularly high frequency of failed PCR. Most of the failed PCR analyses occurred in the plasma samples.

Microsatellite abnormalities were found in the tumour alone in three cases. In the tumour and plasma of case 10 there was loss of heterozygosity for ACTBP2 and a band shift for FgA (fig 1). In case 3 there was an loss of heterozygosity in the plasma only for ACTBP2 for UT762 (fig 2).

Table 2 continued

\begin{tabular}{|c|c|c|c|c|c|c|c|c|c|c|c|c|c|c|c|c|c|}
\hline \multicolumn{3}{|c|}{12} & \multicolumn{3}{|l|}{13} & \multicolumn{3}{|l|}{14} & \multicolumn{3}{|l|}{15} & \multicolumn{3}{|l|}{16} & \multicolumn{3}{|l|}{17} \\
\hline \multicolumn{3}{|c|}{$\begin{array}{l}\text { IDC } \\
65\end{array}$} & \multicolumn{3}{|c|}{ IDC } & $\begin{array}{l}\text { IDC } \\
61\end{array}$ & IDC & & \multicolumn{3}{|c|}{ IMC } & \multicolumn{3}{|c|}{ IDC } & \multicolumn{3}{|c|}{ IDC } \\
\hline \multicolumn{18}{|c|}{$\mathrm{Ax} \mathrm{N}$} \\
\hline $\mathrm{N}$ & $\mathrm{T}$ & $P$ & $\mathrm{~N}$ & $\mathrm{~T}$ & $\mathrm{P}$ & $\mathrm{N}$ & $\mathrm{T}$ & $P$ & $\mathrm{~N}$ & $\mathrm{~T}$ & P & $\mathrm{N}$ & $\mathrm{T}$ & $\mathrm{P}$ & $\mathrm{N}$ & $\mathrm{T}$ & P \\
\hline - & + & + & 0 & 0 & 0 & 0 & 0 & 0 & + & + & - & + & + & + & + & + & + \\
\hline- & + & + & 0 & 0 & 0 & + & + & 0 & + & M & - & + & + & + & + & + & + \\
\hline 0 & 0 & 0 & + & + & 0 & + & + & 0 & + & + & - & + & + & + & + & + & + \\
\hline - & - & + & + & + & 0 & + & + & 0 & + & + & - & + & + & + & + & + & + \\
\hline 0 & 0 & 0 & + & + & 0 & + & + & 0 & + & + & - & + & + & + & + & + & + \\
\hline 0 & 0 & 0 & + & + & 0 & + & + & 0 & + & + & - & + & + & + & + & + & + \\
\hline+ & - & - & 0 & 0 & 0 & + & + & 0 & + & + & - & + & + & + & + & + & + \\
\hline - & + & + & 0 & 0 & 0 & + & + & 0 & + & + & - & + & + & + & + & + & + \\
\hline - & - & + & + & + & 0 & + & + & 0 & + & + & + & + & + & + & + & + & + \\
\hline - & + & + & + & M & 0 & - & + & 0 & 0 & 0 & 0 & + & + & + & 0 & 0 & 0 \\
\hline+ & + & + & + & + & 0 & + & + & 0 & + & + & + & + & + & + & + & + & + \\
\hline
\end{tabular}




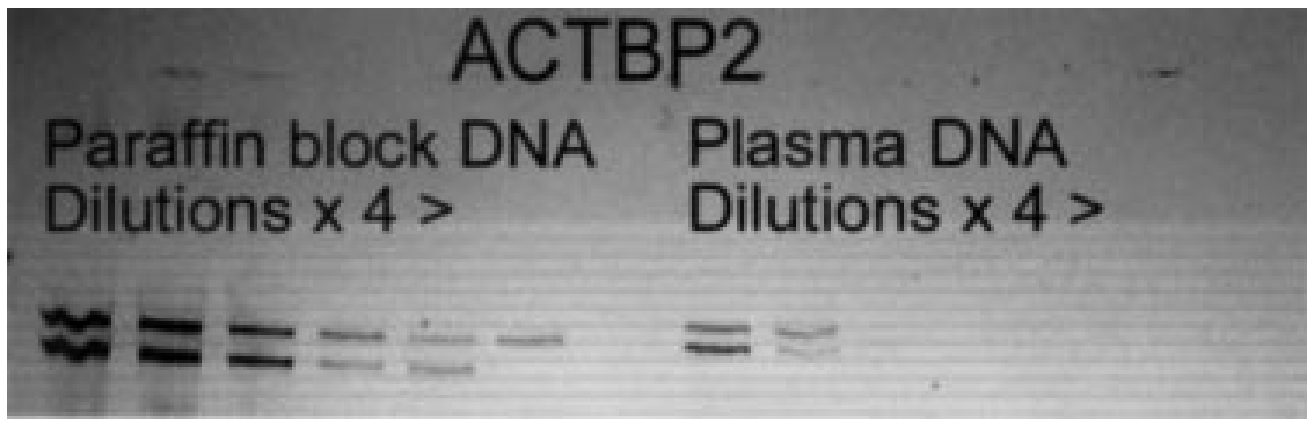

Figure 3 The amplification products of serial dilutions of DNA extracts from formalin fixed, paraffin embedded tissue and from plasma. The first lane of the paraffin extract is the polymerase chain reaction (PCR) product for ACTBP2

(approximately 290 base pairs) from $22 \mathrm{ng}$ of template DNA, and the first lane of the product from plasma is from $24 \mathrm{ng}$ of template. There are five subsequent lanes for paraffin and plasma, with approximately fourfold increases in the template dilution. It appears that there is markedly less efficient amplification from the plasma DNA. In addition there appears to be artefactual loss of heterozygosity in the sixth lane of the paraffin samples, owing to unequal amplification of the two alleles at low template concentrations.

in the plasma samples. None were given to case 3 around the time of her operation.

There is wide variation in the reported frequency of microsatellite abnormalities in breast carcinoma. In 1997 Dillon et al reviewed published reports and found that microsatellite instability was detected in a total of 36 of 276 tumours $(13 \%)^{19}$; the number of instances of microsatellite instability was only 64 of 2499 $(2.5 \%)$. Some studies found none at all and others found microsatellite instability in $85 \%$ of tumours. In their own study of a large series of breast carcinomas, Dillon et al found microsatellite instability in 13 of 733 invasive carcinomas $(1.8 \%)$ but loss of heterozygosity in $75 / 164$ specimens $(46 \%) .{ }^{19}$ We tried to select microsatellite loci that had been shown to have a high frequency of abnormalities in previous studies, particularly in breast carcinomas. For example Paulson et al found 22 of 39 breast carcinomas had microsatellite abnormalities for either GGAA2E02 or GGAA4D07 loci. ${ }^{15}$ We found only one abnormality for GGAA4D07 and none for GGAA2E02. Yang et al found abnormalities for D17S513 in three of 11 breast carcinomas under $2 \mathrm{~cm}$ and nine of 10 carcinomas greater than $2 \mathrm{~cm}^{12}$ We had hoped that by selecting the microsatellites in our study carefully we would obtain a similarly high frequency of abnormalities in the primary tumours that would then make the examination of the plasma potentially informative. However, we found only six abnormalities in 17 cases, despite examining up to 11 different microsatellites. Another frustration was that corresponding plasma samples could be successfully amplified for only two of these. These two both showed identical abnormalities in the plasma. These two abnormalities both occurred in the same tumour (case 10), which was a lobular carcinoma measuring $1.5 \mathrm{~cm}$ across. One showed loss of heterozygosity and the other microsatellite instability. This patient has no evidence of metastatic tumour eight months after surgery, although she did have anaemia of unknown cause. She died about a year after surgery from numerous other medical problems.

The discovery of concordant abnormalities in the plasma and the primary tumour in this case shows that if the technical aspects could be improved then an examination of the plasma for microsatellite abnormalities might have a role in the assessment of breast lesions. However, there would have to be quite a marked increase in the frequency of detectable microsatellite abnormalities in the plasma. Selection of short microsatellites targets, less than about 120 base pairs, would probably improve the frequency of successful amplification from plasma DNA.

1 Leon SA, Shapiro B, Sklaroff DM, et al. Free DNA in the serum of cancer patients and the effect of therapy. Cancer Res 1977;37:646-50.

2 Mulcahy H, Croke D, Farthing M. Cancer and mutant DNA in blood plasma. Lancet 1996;348:628.

3 Stroun M, Anker P, Lyautey J, et al. Isolation and characterisation of DNA from the plasma of cancer patients. Eur 7 Clin Oncol 1987;23:707-12.

4 Stroun M, Anker P, Maurice P, et al. Neoplastic characteristics of the DNA found in the plasma of cancer patients. Oncology 1989;46:318-22.

5 Fournié GJ, Courtin JP, Laval F, et al. Plasma DNA as a marker of cancerous cell death. Investigations in patients suffering from lung cancer and in nude mice bearing human tumours. Cancer Lett 1995;91:221-77.

6 Vasioukhin V, Anker P, Maurice P, et al. Point mutations of the N-ras gene in the blood plasma DNA of patients with myelodysplastic syndrome or acute myelogenous leukaemia. Br f Haematol 1994;86:774-9.

7 Chen XQ, Stroun M, Magnenat J, et al. Microsatellite alterations in serum DNA of small cell lung cancer alterations in serum DNA of small

8 Nawroz H, Koch W, Anker P, et al. Microsatellite alterations in serum DNA of head and neck cancer patients. Nature in serum DNA of h.

9 Anker P, Lefort F, Vasioukhin V, et al. K-ras mutations are found in DNA extracted from the plasma of patients with colorectal cancer. Gastroenterology 1997;112:1114-20.

10 Mayall F, Jacobson G, Wilkins R, et al. p53 gene mutations can be detected in the plasma of patients with large bowel carcinoma. F Clin Pathol 1998;51:611-13.

11 Gemmell N, Akiyama S. An efficient method for the extraction of DNA from vertebrate tissues. Trends Genet 1996;12: 338-9.

12 Yang X, Russo I, Huang Y, et al. Microsatellite instability of D17S513 on chromosome 17 is associated with the progression of breast cancer. Int $\mathcal{F}$ Oncol 1997;11:41-6.

13 Chen XQ, Stroun M, Magnenat J, et al. Microsatellite alterations in serum DNA of small cell lung cancer alterations in serum DNA of small

14 Nawroz H, Koch W, Anker P, et al. Microsatellite alterations in serum DNA of head and neck cancer patients. Nature in serum DNA of head $1996 ; 2: 1035-7$.

15 Paulson TG, Wright FA, Parker BA, et al. Microsatellite instability correlates with reduced survival and poor disease prognosis in breast cancer. Cancer Res 1996;56:4021-6.

16 Rosenberg C, de las Morenas A, Huang K, et al. Detection of monoclonal microsatellite alterations in atypical breast hyperplasia. F Clin Invest 1996;98:1095-100.

17 Yee C, Roodi N, Verrier C, et al. Microsatellite instability and loss of heterozygosity in breast cancer. Cancer Res 1994;54:1641-4.

18 Mao L, Lee D, Tockman M, et al. Microsatellite alterations as clonal markers for the detection of cancer. Proc Natl Acad Sci USA 1994:91:9871-5.

19 Dillon EK, de Boer WB, Papadimitriou JM, et al. Microsatellite instability and loss of heterozygosity in mammary carcinoma and its probable precursors. $\mathrm{Br} \mathcal{F}$ Cancer 1997;76:156-62. 